Lochrie, S., Baxter, I., Collinson, E., Curran, R., Gannon, M., Taheri, B., Thompson, J. \& Yalinay., O. (2019). Self-expression and play: Can religious tourism be hedonistic?, Tourism Recreation Research, DOI: 10.1080/02508281.2018.1545825

\title{
Self-expression and play: Can religious tourism be hedonistic?
}

\begin{abstract}
Using data collected from 538 Iranian tourists undertaking the religious pilgrimage of Umrah (i.e., voluntary travel to the holy city of Mecca at any time throughout the year), this study investigates the concept of play and its relationship with self-expression and hedonism in an Islamic tourism context. By testing a theoretically derived structural model, the findings suggest that self-expression strongly influences tourists' sense of play. Here, play is realised when tourists feel that they can express themselves freely and augment their self-image while travelling, irrespective of the religious context. Nonetheless, the pilgrimage environment is characterised by religious congregation - with tourists engaging in communal experiences that reflect themselves and their faith. Therefore, the ideal experience, where tourists feel a sense of escapism from the pressures of everyday life, is a product of their ability to project, develop, and ratify their self-concept. Finally, the study suggests that pilgrimage managers and marketers should focus on the importance of play, enabling their destinations to heighten the intensity of the 'enjoyable' elements of religious travel (e.g., group camaraderie, escapism and positive emotional reactions) alongside their inherent religious benefits.
\end{abstract}

Keywords: Play; self-expression; hedonism; pilgrimage; religious tourism 


\section{Introduction}

Islamic tourism represents the unusual union of religion and leisure, and serves as one notable example of the contemporary interpretation of pilgrimage (Jafari \& Scott, 2014). Unlike its mass-market counterparts, Islamic tourism is not typically considered to embody the hedonic characteristics of travel (Henderson, 2009). Instead, emphasis is placed on its inherent religious and spiritual importance, underpinned by opportunities for self-reflection and communal worship (Sonmez, 2001). Nonetheless, given its fundamental association with the movement of people across national and international borders, it is unsurprising that interest in 'pilgrimage' continues to flourish within the domain of tourism research (Aukland, 2017; Gannon et al., 2017).

Similarly, many religious sites are internationally recognized as holding significant cultural importance, with visitor numbers to match (Fleischer, 2000; Jutla, 2002). For example, two million visitors travelled to the holy city of Mecca while undertaking Hajj in 2017 (Smith, 2017). While studies debate the differences between 'tourist' and 'pilgrim', and their motivations for visiting sacred destinations (Sharpley \& Jepson, 2011; Hellman, 2017), pilgrims nonetheless exhibit many of the same characteristics, behaviours, and expectations as general tourists (Gannon et al., 2017). As such, while the spiritual disposition of pilgrims has traditionally been given priority over the materialistic or secular outcomes emerging from such travel (Nyaupane et al., 2015); recent studies question this approach (Taheri, 2015). Thus, this study aims to further explore this disparity by considering some of the lessspiritual characteristics of pilgrimage. In order to do so, we examine whether 'selfexpression' and 'play' stimulate perceived hedonic value within the context of Islamic tourism.

To this end, religious tourists undertaking pilgrimage do not eschew everything we have come to know about their secular counterparts. Such pilgrims still seek high quality experiences, opportunities to socialise, appropriate accommodation, and the prospect of experiencing and ingratiating themselves with the local culture (Gannon et al., 2017). As such, despite its haughty and edifying characteristics, pilgrimage may offer opportunities for Islamic tourists to engage in 'play'. Play is an important emotional state or activity and is defined by Barnett (2000, p.442) as a 'behavioural disposition, characterised by pleasure, enjoyment, freedom and spontaneity, which elicits engagement by participants and which is manifest in a variety of different forms'. Given its focus on sensuality and euphoria, it is 
understandable that play has been afforded considerable attention within extant tourism discourse (Gyimóthy \& Mykletun, 2004), with some contextual focus on the importance of sacred rituals and pilgrimage (Belk et al., 1989). However, other significant elements of the tourist experience relate to self-expression and hedonism. Self-expression is associated with involvement and consumption. Simply, participation, whether by obtaining a specific product or actively being in a particular situation, goes some way to demonstrating to others who the individual is and acts as a medium through which tourists can augment their self-image (Prayag \& Hosany, 2014; Whiting \& Hannam, 2015). Further, within the consumption experience hedonism relates to intangible, multi-sensual emotions felt by consumers (Hirschman \& Holbrook, 1982) and is regularly considered when assessing tourists' travel evaluations.

Both self-expression and hedonism are intricately associated with the notion of play (McGinnis et al., 2008; Wearing et al., 2013). Nonetheless, despite their ubiquity in tourism research, there remains little investigation into neither the relationships between selfexpression, play and hedonic value, nor their importance specific to the Islamic tourism context (Taheri, 2015). Therefore, this study is underpinned by a desire to examine whether self-expression and play stimulate perceived hedonic value within this context. By addressing this gap, it contributes to the growing body of knowledge on Islamic tourism by enhancing nascent understanding of the effect of self-expression on play, and the subsequent impact of both on the hedonic value derived from this under-researched form of tourism (Dallen \& Olsen, 2006). This is underpinned by the notion that when tourists express themselves and openly engage with consumption experiences, their sense of 'play' and the perceived hedonic value derived from such travel increases.

The paper continues by first discussing literature focused on the concepts of play (underpinned by communitas, flow and ecstasy), self-expression, and hedonism. Next, hypotheses and a newly developed conceptual model are presented, with the structural model subsequently tested using data collected from Iranian tourists travelling to Mecca, Saudi Arabia, on the voluntary religious pilgrimage of Umrah. While important in terms of conveying religious devotion, Umrah can nonetheless 'be undertaken at any point throughout the year and is not considered compulsory" when compared to Hajj, which is obligatory and considered 'one of the five pillars of Islam' (Gannon et al., 2017, pp.448-449). In doing so, this study also advances the application of partial least squares structural equation modelling (PLS-SEM) in tourism research. The paper concludes by discussing the theoretical and managerial implications of the findings, with suggestions for future research also presented. 


\section{Literature Review}

Academic interest in the psychological antecedents of religious tourism is long established, with emphasis often placed on the inherent religiosity, spirituality, and sociality of such travel (Delener 1994; Mathras, Cohen, Mandel, \& Mick, 2016). Having shaped much of human history, religiosity nonetheless remains an important contemporary cultural phenomenon capable of influencing individuals' attitudes, values and behaviours (Eid \& El-Gohary, 2015; Spilka, Hood, Hunsberger \& Gorsuch, 2003; Zamani-Farahani \& Musa 2012). Schmidt et al. (1999, p.10) define religion as 'systems of meaning embodied in a pattern of life, a community of faith, and a worldview that articulates a view of the sacred and of what ultimately matters'. From a psychological perspective and by adapting Schmidt et al.'s (1999) definition, Mathras et al. (2016) and Saroglou (2011) stress that religion influences consumer behaviour via four dimensions: beliefs, rituals, values, and community. In marketing studies, the concept of religion is largely concerned with segmentation, brand relationships, and compensatory consumption (Spilka, Hood, Hunsberger, \& Gorsuch, 2003). However, Islamic marketing literature also highlights the influence of religion on consumer behaviour and purchasing decisions (El-Bassiouny, 2014; Taheri, 2015; Fam, Waller, \& Erdogan, 2004). As such, religious tourism can be considered a subset of general tourism, imbued with the same concerns surrounding consumption and behaviour, nonetheless differentiated by its emphasis on visiting and engaging with religious destinations (Albayrak et al., 2018; Terzidou, Scarles, \& Saunders, 2018; Jafari \& Scott, 2014).

To this end, Muslim tourists evaluate destinations not only through their value as pilgrimage sites (i.e., travel underpinned by the importance of Islamic values) but also in terms of their leisure offerings (i.e., experientially engaging in the cultural consumption process and interacting with others) (Albayrak et al., 2018; Jafari \& Scott, 2014). Psychological constructs such as cosmopolitanism, self-identity, socialization, engagement, emotional connection, and involvement (Albayrak et al., 2018; Gannon et al., 2017; Jafari \& Scott, 2014; Taheri et al., 2016; Terzidou et al., 2018), have been studied within the context of religious tourism. However, extant research in the area is not exhaustive, and our overall understanding of the psychological constructs that influence Islamic tourism remains incomplete. As such, by considering self-expression, play, and hedonism within this distinct context, this study may shed further light on the assertion that Islamic tourism is underpinned by the two-way interaction between the tourist and the destinations that they visit. 


\section{Play and Pilgrimage}

Definitions of 'play' often emerge from the notion of self-determined freedom without restrictions (Turner, 1969). Across research exploring consumption, play is a prevalent construct (McGinnis et al., 2012), and McGinnis and Gentry (2004, p.407) argue that when individuals experience 'play' in the context of undertakings perceived as sacred, it makes 'the meaning of [the] activity more salient and more memorable'. They continue by asserting that, 'play in the context of a sacred ritual experience can be defined in terms of communitas, flow, and ecstasy' (McGinnis \& Gentry, 2004, p.407). As such, in order to investigate this assertion further, we turn to Islamic pilgrimage and Islamic tourism as a less immediately obvious vessel for play, nonetheless endowed with the requisite mechanisms to stimulate feelings of communitas, flow, and ecstasy in those undertaking such travel.

Pilgrimage represents the 'journey resulting from religious causes, externally to a holy site, and internally for spiritual purposes and internal understanding' (Barber, 1993, p.1) and, given its emphasis on both the journey and destination, it has long served to interest tourism scholars (Collins-Kreiner, 2010; Moufahim \& Lichrou, 2019). Here, focus has been placed on exploring and understanding the characteristics, motivations, and experiences of those undertaking religious travel (Collins-Kreiner \& Kliot, 2000; Devereux \& Carnegie, 2006). To this end, extant research recognizes the role of pilgrims as consumers, albeit with an emphasis on experiencing, interacting with, and engaging with objects and artefacts of established spiritual importance (Scott \& Maclaren, 2013; Moufahim \& Lichrou, 2019). Therefore, it is important to recognise that while pilgrimage is underpinned by spirituality and religiosity, this is not necessarily religious travellers' sole concern in practice (Gannon et al., 2017). Indeed, this study is underpinned by the assumption that pilgrims share many of the same characteristics and motivations as non-religious tourists (Collins-Kreiner, 2010), moving beyond the functional and reductive notion that pilgrimage should be considered exclusively as 'journeying to a sacred place or shrine as a devotee' (Griffin, 2007, p.16). Indeed, extant research suggests that religious travel, including pilgrimage, can be imbued with a range of hedonic aspects from which pleasure is derived (e.g., souvenir purchases, general recreation, and opportunities for relaxation) (Dallen \& Olsen, 2006); social considerations, such as sharing the pilgrimage experience with family and friends, or of feeling a part in a wider collective of likeminded individuals (Gannon et al., 2017); and hedonic feelings of immersion, involvement, complicity and participation (Hellman, 2017) which together may reinforce notions of play. Therefore, given the aforementioned potential 
for religious tourism to stimulate feelings of communitas, flow, and ecstasy, irrespective of the Islamic tourism context, we respect Taheri et al.'s (2016) call for conceptualizing play as a second-order multi-dimensional construct comprised of three sub-scales: 1) communitas, 2) flow, and 3) ecstasy. Here, we thus echo Vukonic (1996), who suggests that pilgrims undertake religious travel to satisfy both their spiritual and material needs, further blurring the distinction between traditional pilgrim and contemporary religious tourist.

\section{Play: Communitas, Flow and Ecstasy}

As mentioned prior, play is conceptualised by Taheri et al. (2016) as a second-order multidimensional construct underpinned by three first-order dimensions: communitas, flow, and ecstasy. Here, communitas is described as a situation where the social order is 'an undifferentiated, homogeneous whole, in which individuals confront one another integrally, and not 'segmentalised' into statuses and roles' (Turner, 1969, p.177). Communitas therefore represents an exceptional experience shared with others. When a sense of communitas is manifest, individuals' existing social, professional and economic characteristics are secondary - with the shared experience and emotions attached forthwith considered paramount (Sharpe, 2005; Wichmann, 2017). As a result, there is a sense of belonging; a harmony with those sharing the experience and a sense of mutuality, offering the opportunity to gain greater understanding of the place, beliefs, and experiences converging to produce this communal spirit of togetherness (Wichmann, 2017).

Communitas serves as the catalyst for developing connections to likeminded individuals, with emphasis often placed on those holding similar interests with regards to religion, sport, or music and the sense of belonging that can emerge from such interactions. With this in mind, some tourists are motivated by travel that provides them with the opportunity to meet new people (Cordina, Gannon \& Croall, 2018), whereas others consider it a fortunate by-product of tourism. The importance of communitas is central to discourse on collective and experiential consumption activities, such as festival tourism (Crompton \& McKay 1997), white-water rafting (Arnould \& Price, 1993), skydiving (Celsi et al., 1993) and the World Gymnaestrada (Wichmann, 2017). Communitas has also been investigated with regards to tourists' consumption of the 'sacred' (McGinnis et al., 2012). Further, the 'need' to experience communitas, and the desire to revel in the spirit of community, has an impact on tourists' perceptions of the sanctity of certain pursuits (McGinnis et al., 2001), and 
it can thus solidify and develop consumption practices and subsequently act as 'vehicles for experiencing the sacred' (Belk et al., 1989, p.1).

There are a number of ways in which communitas is engendered through shared experiences in places of religious importance. Pilgrimage occurs in all major religions (Collins-Kreiner \& Kliot 2000; Dallen \& Olsen, 2006; Jutla, 2002) and is generally considered as serving a dual purpose; internally to reinforce faith and religiosity, and externally as the functional travel to sites of established spiritual importance (Barber, 1993). However, this reductive view of pilgrimage is being superseded by acknowledgement of the importance of the social elements of pilgrimage, which extends beyond the religious emphasis on friendship and family (Hyde \& Harman, 2011).

Therefore, the second dimension underpinning play is flow (Taheri et al., 2016), which is described as 'the holistic experience people feel when they act with total involvement' (Csikszentmihalyi, 1975, p.36). When experiencing flow, individuals lose track of their self-consciousness and time, making such experiences both unforgettable and effortless (Vitterso et al., 2001). As with communitas, the links between flow and pilgrimage have been acknowledged (Turner, 1969). Here, those who experience flow may believe that the domain in which it occurred is sacred (McGinnis et al., 2008). As a result, tourists often remember those places that they have visited - where they have felt a sense of flow - with admiration and pleasure (McGinnis et al., 2008). Research has suggested that flow is core to the leisure experience (Heo et al., 2010), due to the acknowledgment that contemporary leisure activities (and indeed tourists) are underpinned by a focus on providing/gaining specific experiences (Vespestad \& Lindberg, 2011).

As such, discourse suggests that destination marketers should focus on encouraging feelings of escapism, adventure, and participative involvement among tourists (Mannell \& Iso-Ahola, 1987). Tourism stimulates the ideal circumstances for experiencing intensified states of being (i.e., flow) (Heo et al., 2010) and, due to the exceptional nature of many travel experiences; flow is considered enchanting and addictive (Celsi et al., 1993). Therefore, it consequently affects the tourists' satisfaction levels and intentions to revisit or recommend destinations (Gannon et al., 2017; Thompson et al., 2018). To this end, numerous studies have identified the relationship between flow and hedonic value (McGinnis et al., 2008) and the subsequent derivation of positive emotions and enjoyment (Wu \& Liang, 2011). 
Finally, ecstasy and its related emotional concepts (i.e., overwhelming joy and pleasure) are associated with an individual's attendance or consumption of events, activities, and/or experiences (Belk et al., 1989). Such consumption experiences are considered positive if feelings of ecstasy are stimulated in the consumer (Fillis \& Mackay, 2014), and this intertwines with the other components of play (McGinnis et al., 2008). Similar to communitas and flow, ecstasy emerges from activities that require immersion in the process (Taheri et al., 2016). Across tourism studies, play also affects consumers' participation in interactive environments (Taheri et al., 2016). For example, exploring adventure tourism in the Artic, Gyimóthy and Mykletun (2004) found that play was associated with the adventurers' pursuit of 'high arousal'. Ecstasy has been linked to attendance at religious sites, events, and pilgrimage (McGinnis \& Gentry, 2004; Turner \& Turner, 1978; Taylor \& Taylor, 1997).

There is a natural spiritual connection associated with attendance at religious events, which can reassure one's faith, result in pleasure through a sense of belonging and togetherness, or simply emerge through a sense of awe and wonder inspired by the sanctity of the place and/or journey (Mazumdar \& Mazumdar 2004; Taylor \& Taylor, 1997). This uplifting sense of spirituality and ratification of faith can result in elation, which transcends that of normal, everyday religious experiences (Belk et al., 1989; Grappi \& Montanari 2011; Jafari \& Scott, 2014). As such, as vehicles for play, religious tourism and the pilgrimage environment may stimulate feelings and outcomes that are not necessarily considered 'religious', with emphasis on the non-spiritual, intrinsic, and hedonic value derived by the tourist in such circumstances. Indeed, Eid and El-Gohary (2015) highlight three analogous constructs which reinforce the importance of play in stimulating satisfaction within an Islamic tourism context: the traditional social and emotional value derived from such travel, alongside value underpinned by the 'Islamic non-physical attributes'. As such, given the ubiquitous importance placed upon shared worship (i.e., social value) and its inherent ability emotionally stimulate tourists (Henderson, 2009), the pilgrimage context may provide the ideal circumstances to foster the sense of communitas and ecstasy crucial to ensuring tourists experience 'play' (Taheri et al., 2016).

\section{Self-expression and Hedonism}

Self-expression is 'the degree to which participants express their self-concept or individuality through the situation or object of study' (Gross \& Brown, 2008, p.1141). Self-expression is 
linked to the concept of conspicuous consumption, implying that individuals derive pleasure from activities which demonstrate their stature, knowledge, tastes, and social-standing (Schau et al., 2009). Stemming from the suggestion that behaviour is influenced by a desire to confirm self-image, one of the core facets of conspicuous consumption is that individuals use products to convey their identity to others (Kleine III et al., 1993). In the tourism context, self-expression is important (Prayag \& Hosany, 2014; Whiting \& Hannam, 2015), as it is serves as the symbolic meaning people give to specific leisure activities (Gross \& Brown, 2006). To this end, destination-choice and participation in activities therein serve as a means to express individuality and contribute to crafting the impression tourists hope to convey to others (Kyle \& Chick, 2002).

Self-image has a role in influencing the destinations that individuals elect to visit (Moore et al., 1995), with many studies considering the role of self-expression in exploring elements of the tourist experience. For example, research contends that, if an individual ascribes robust personal meaning to a leisure activity, they are more likely to experience feelings of ecstasy or hedonic value (Jang et al., 2000; Prayag \& Hosany, 2014; Wearing et al., 2013). Others highlight the positive relationship between self-expression and elements of 'play' (Hopkinson \& Pujari, 1999; McGinnis et al., 2008). Here, when exploring enduring involvement with extended service encounters, McGinnis et al. (2008) found positive relationships between flow and communitas on self-expression. This is supported by research identifying the links between self-expression and communitas (McGinnis \& Gentry, 2004). These studies highlight that meaning in consumption often ascends from self-expression, communitas, and a close connection to others (Hopkinson \& Pujari, 1999).

As such, extant research highlights the associations between a tourist's ability to express their individuality through consumption experiences imbued with elements of play communitas, flow and ecstasy (Hopkinson \& Pujari, 1999; McGinnis \& Gentry, 2004). An individual has the potential to experience play if they are in an environment, or have access to a specific artefact, which helps to convey and amplify their self-image (McGinnis et al., 2008). Indeed, within the Islamic tourism context this may hold greater emotional value (Moufahim \& Lichrou, 2019), where the very act of undertaking pilgrimage can help to strengthen an individual's religious identity, with travel and any associated consumption onsite serving as the physical manifestation of this religious self-expression and the sense of flow and communitas experienced therein (Eickelman \& Piscatori, 2013). It is thus likely that self-expression positively influences play and, within the context of those travelling for Umrah, this study therefore hypothesizes: 
H1. Self-expression is positively related to play.

Further, within the consumption experience, hedonism relates to the intangible, multisensual emotions felt by consumers (Hirschman \& Holbrook, 1982). Through consumption, hedonism stimulates feelings of arousal, fantasy, enjoyment and pleasure (Babin et al., 1994; Grappi \& Montanari, 2011). In the post-consumption evaluation process, hedonism features significantly (Babin et al., 1994). It is important to tourism (Hightower Jr. et al., 2002), where the purchase of tourism products and services are often inherently hedonic in nature (Curran et al., 2018). Hedonism is also positively associated with high levels of satisfaction and is linked to feelings of excitement and ecstasy (Dunham et al., 2006). Therefore, hedonism is a fundamental element of experiential consumption (e.g., tourism) and lives-long within an individual's memory (Mannell \& Kleiber, 1997).

Hedonism is also associated with communitas (Arnould \& Price, 1993), with Hopkinson and Pujari (1999, p.274) highlighting that when '...the individual enters a transcending community of camaraderie the individual also experiences ecstasy and flow'. Therefore, hedonism, ecstasy and flow can be regarded as closely associated (Hopkinson \& Pujari, 1999; McGinnis et al., 2008). However, this is not necessarily solely a contemporary concern. Historically, the purpose of undertaking a pilgrimage was partially based on the hedonic value derived from the journey, process, and experience. This is based on the notion that pilgrimage offers travellers 'an adventure, an escape, or a chance to experience worldly pleasures denied them at home' (Hyde \& Harman, 2011, p.1345). However, as time has elapsed, and the religious importance of tourism and heritage sites has continued to develop, the personal pleasure derived from visiting such sites has been considered secondary (Gannon et al., 2017). Nonetheless, extant research does provide evidence to support the hedonic value of the journey and experience manifest post-pilgrimage, particularly in an Islamic context (Gannon et al., 2017; Taheri, 2015).

Hedonism is also important in establishing tourists' satisfaction and memories, as it has the ability to influence their future behaviours (Wearing et al., 2013). For example, the hedonic feelings of patronage are positively associated with the intention to recommend an experience to others (Grappi \& Montanari, 2011; Hosany \& Gilbert, 2010). Service providers must therefore ensure that their offering fosters hedonistic feelings (Arnold \& Reynolds, 2012; Mason \& Paggiaro, 2012). In doing so, they may take advantage of the emotional value experienced while undertaking pilgrimage, where visitors derive pleasure from the positive emotions engender through visiting such sites (Gannon et al., 2017). Just as leisure tourists 
derive pleasure from positive travel experiences (Mason \& Paggiaro, 2012); pilgrims may derive hedonic value when their visit exceeds their expectations. For those tourists already familiar with the significance of a pilgrimage site, their interest can be solidified through visitation and the experience itself. Indeed, such travel is encouraged in Islam, where believers are encouraged to experience the 'Greatness of God' through travel (Eid \& ElGohary, 2015; Jafari \& Scott, 2014; Taheri, 2015). This can be self-affirming in so much as their belief can be reinforced, or their decision to travel what is often significant distance to a site can be justified to themselves on the basis that the experience was enjoyable, informative, and reassuring - with hedonic value derived from this experiential faith affirmation.

Nonetheless, some scholars suggest that hedonism and religiosity occupy different ends of the psychological spectrum (Roccas, 2005; O’Shaughnessy \& Jackson-O'Shaughnessy, 2002). Yet, pilgrimage represents a vessel for symbolic consumption, 'where the sacred and the profane overlap and where exploration of the relationship between religion, spirituality, and consumption can be undertaken' (Moufahim \& Lichrou, 2019, p.322). While the hedonic value of symbolic consumption is long established (Allen, 2001), the sanctity of Islamic tourism represents an interesting, under-explored manifestation of this couched within the confines of religion (Moufahim \& Lichrou, 2019). To this end, and within the context of Islamic tourism, Eid and El-Gohary (2015) suggest that the hedonic value derived from consumption contributes to the level of satisfaction experienced by Muslim tourists.

As such, both play and self-expression are expected to have a positive influence on hedonism (Arnould \& Price, 1993; Hopkinson \& Pujari, 1999; McGinnis et al., 2008). Given that play is related to feelings of heightened enjoyment, the loss of one's self in the moment, ability to escape everyday reality, and joy derived from a connection with similar groups of people (Wu \& Liang, 2011), the relationship to the stimulation of hedonic feelings is expected to be positive. The ability for an individual to project their self-concept and express themselves through an experience is also suggested to link positively to hedonism (Prayag \& Hosany, 2014; Schau et al., 2009). Therefore, as per Figure 1, this study hypothesizes:

H2. Play is positively related to hedonism.

H3. Self-expression is positively related to hedonism.

Finally, while tourism literature hypothesizes the direct effect of self-expression on hedonism (Eid \& El-Gohary, 2015; Gannon et al., 2017), and the direct effect of play on hedonism (McGinnis et al., 2012; Taheri, Farrington, Gori, Hogg, \& O’Gorman, 2017), few studies 
evaluate the indirect effects of play on the relationship between self-expression and hedonism. Hence, this study proposes the following hypothesis centred on examining the mediating role of play:

H4: Play mediates the relationship between self-expression and hedonism.

\section{[Figure 1 here]}

\section{Research Methodology}

\section{Data Collection}

The focus of this study is Iranian tourists to the holy city of Mecca (Saudi Arabia) for the purpose of Umrah. Jafari and Scott (2014) describe Umrah as a smaller pilgrimage experience and a voluntary trip when compared to the compulsory Hajj. Hajj is therefore considered a more serious religious pilgrimage experience, as it is obligatory for Muslims to undertake it at-least once in their lifetime, during a specific period, whereas Umrah can be undertaken at any time throughout the year (Gannon et al., 2017). The data was collected via a self-reported survey of Iranian tourists who had undertaken Umrah on organised tours with travel agencies, and who had subsequently returned to Iran. The agents used paper copies of the survey to collect data, and one member of the research team remained present to answer any questions arising from participants. Overall, 650 surveys were distributed, with 538 usable responses obtained. Here, Hair et al. (2017) suggest that the sample size must be ten times larger than the highest number of items used to capture a single construct. In this study, the highest number of items belongs to the ecstasy, communitas and flow constructs (yielding a minimum sample size of 70). The $G^{*}$ Power demonstrates that the sample size for this study is appropriate as, to generate a power of 0.95 for the conceptual model, the minimum sample required would be 138 respondents (Faul et al., 2009).

A back-translation approach was used to convert the survey into Farsi, the native language of Iran, in order to ensure an accurate translation. A pilot test was undertaken, which was vital in confirming that all statements within the survey were clear to participants. Overall, the sample was comprised of: $47.4 \%$ male and $52.6 \%$ female. $10.5 \%$ of participants were between 18 and 35 years old, 14.5\% were between 36 and 45 years old, 29\% were between 46 and 55 years, and $46.1 \%$ of the sample was 56 years old or older. Non-response bias was also tested. Early and late versions of the questionnaire were compared for any systematic differences in socio-demographic attributes, with none identified between these groups (Armstrong \& Overton, 1977). 
With regards to the quality of the data collected, the possibility of the violation of common method bias was also tested for. As the dependent and independent variables were collected from the same destination in a single contextual setting, common method bias could have become a problem for this study (Podsakoff et al., 2003). In response to this, the survey also included several additional construct items in order to dilute the probability of participants guessing the potential relationships outlined in the conceptual model. Further, the dependent and independent variables were allocated to different parts of the questionnaire. Two statistical tests were also used to detect possible threats: (1) Harman's single-factor test was used to test for CMV. The results of the exploratory factor analysis (EFA) exposed six factors with Eigenvalues above 1, and the highest portion of variance described by one factor was 40.641\% (Podsakoff et al., 2003). (2) Following Liang et al.'s (2007) procedure, a common method factor was presented to the PLS model. The common method factor embraces all indicators of the model. While the constructs of the model explain 0.66 on average, the common method factor only explains 0.01 on average, yielding an acceptable ratio of $66: 1$. Hence, this suggests that CMV is not a concern in this study.

To ensure content validity, the statements of all constructs were adapted from scales established in extant literature. All items were measured with a 7-point Likert scale (from $1=$ 'strongly disagree' to $7=$ 'strongly agree'). Self-expression has six items, and was adapted from Gross and Brown (2006; 2008). Further, respondents indicated their level of agreement regarding general involvement and feelings towards tourism activities. Play, the second-order construct, was formed reflectively by three first-order dimensions, adapted from Taheri et al. (2016) and McGinnis et al. (2012): (1) Communitas (6 items), (2) Flow (7 items), and (3) Ecstasy ( 7 items). Thus, the second-order play construct is comprised of 20 items in total. For each, the respondents indicated their level of agreement during their Umrah experience. Hedonism was measured with 4 items borrowed from Grappi and Montanari (2011). Again, the respondents indicated their level of agreement regarding their travel experience while undertaking Umrah.

\section{Analytical technique}

Partial least squares structural equation modelling (PLS-SEM) was employed to analyse the research model for a variety of reasons. First, PLS-SEM does not require the data to be normally distributed (Hair et al., 2017; Smith \& Ram, 2017). For this study, a multivariate normality examination (by calculating z-scores for kurtosis and skewness for all items) was 
used. The results showed that some items held skewness and kurtosis above the mandatory cut-off point of either -3 or +3 (Wells et al., 2016). Second, PLS-SEM can deal with complex models compared to covariance-based SEM (Wells et al., 2016). Third, it can be used in reflective, formative and higher-order modes (Hair et al., 2017; Lee, Hallak, \& Sardeshmukh, 2016; Taheri, Jafari, \& O'Gorman, 2014). In this study, both higher-order and reflective constructs were used, and the measurement and structural models were investigated within SmartPLS 3.0 (Ringle, Wende, \& Becker, 2014).

\section{Results}

\section{Analysis of Reflective Measurement Models}

The reliability and validity of the reflective constructs was tested using composite reliability (CR), Cronbach's Alpha ( $\alpha$ ), factor loadings, and average variance extracted (AVE). The factor loadings, $\mathrm{CR}$, and $\alpha$ all showed values above the obligatory threshold of 0.7 (Hair, Black, Babin, \& Anderson, 2010). The AVE surpassed the threshold of 0.5 for all constructs (Hair et al., 2010) (Table 1). Finally, discriminant validity was tested following Fornell and Larcker's (1981) criterion, which requires a construct's AVE to be larger than the square of its largest correlation with any other construct (Table 2). Further, Henseler, Ringle, and Sarstedt (2015) highlight that the heterotrait-monotrait ratio of correlations (HTMT) approach indicates superior performance (by means of a Monte Carlo simulation) when compared to the Fornell-Larcker criterion. In this study, all HTMT values were below the threshold (0.85), ranging from 0.172-0.675. HTMT $_{\text {inference }}$ criterion (using complete bootstrapping) was calculated; all HTMT values differed significantly from 1 (ranging from 0.358 to 0.721 ) (Wells et al., 2016). Thus, discriminant validity was established.

\section{[Table 1 and 2 here]}

\section{Analysis of the Play Higher-order Model}

In order to establish 'play' as a higher-order construct with a second-order factor characterised reflectively by three first-order dimensions, an EFA test with an Oblique Rotation was performed. Here, the results demonstrated that the second-order 'play' construct was represented by 3 underlying dimensions. All items' loadings were above the minimum threshold ( $\geq 0.5$ ) (Hair et al., 2010). As indicated in Table 1, the three first-order constructs (communitas, flow and ecstasy) showed values above the recommended suggestion for CR, Cronbach's Alpha, and AVE. Finally, the repeated measures approach for estimation of the hierarchal component models (HCMs) in PLS was employed (Becker et al., 2012; Lee et al., 
2016). Following the HCMs procedure, all items for the three first-order constructs were assigned to their respective constructs reflectively. All 20 items underpinning 'play' were connected reflectively to the second-order play construct (Figure 2) and the three first-order constructs were reflectively linked to the second-order construct. The results indicated that the relationship between the three first-order constructs and the second-order construct were strong and significant $(\mathrm{p}<0.05)$ with $\mathrm{R}^{2}$ values higher than 0.5 . Further, the play construct explained more than $50 \%$ of the variance in its respective single-order constructs (Figure 2). As such, the results supported the assertion that play serves as a second-order construct, represented reflectively by the three dimensions of communitas, flow, and ecstasy.

[Figure 2 here]

\section{Structural Model Analysis}

After confirming the measurement model, the hypothesised relationships among constructs was tested through PLS to determine: (1) path coefficients, (2) Effect sizes $\left(f^{2}\right)$, and (3) the $\mathrm{R}^{2}$ values of the endogenous variables (Figure 2) and Standardised Root Mean Square Residual (SRMR) fit index (Hair et al., 2014; Henseler et al., 2016). A nonparametric bootstrapping procedure was used to test the structural model (Hair et al., 2017). As shown in Figure 2, self-expression has a strong positive and significant influence on play (H1: $\beta=$ $\left.0.776, p<.001 ; f^{2}=0.514\right)$. Play has a positive and significant impact on hedonism $(\mathbf{H 2}: \beta=$ $\left.0.30, p<.001 ; f^{2}=0.126\right)$. Finally, self-expression has a positive and significant influence on hedonism (H3: $\left.\beta=0.525, p<.001 ; f^{2}=0.281\right)$. The $f^{2}$ values for the three hypothesised paths were all above 0.02 , suggesting satisfactory effects for the endogenous latent constructs. The SRMR value was 0.046; less than the recommended value of 0.08 (Henseler et al., 2016).

Following Williams and MacKinnon (2008) and Lee et al.'s (2016) recommendation, mediation analysis within the bootstrapping method was used. This technique designates that if the direct effect between two constructs is significant, the results demonstrate partial mediation. However, if the direct effect between two constructs is not significant, the findings indicate full mediation. The results indicated that self-expression indirectly impacts on hedonism through play (CI: $0.143-0.308)$. As the direct influence was significant, the findings showed that play partially mediates the impact of self-expression on hedonism, confirming H4.

\section{[Table 3 here]}




\section{Discussion and Implications}

Using data collected from Iranian tourists who travelled to Mecca and experienced Umrah, this study aimed to gain greater understanding of the concept of play and its relationship to self-expression and hedonism in a novel and under-explored context. A theoretically derived structural model was thus developed to explore the relationships between play, selfexpression and hedonism within the domain of Islamic tourism. The findings highlight significant relationships among the constructs, with these relationships and theoretical implications now discussed. First, the analysis of the conceptual model reveals the potency of play as a second-order construct underpinned by communitas, flow and ecstasy. Therefore, the analysis supports the assertion that these three dimensions serve as one aggregated construct - play (McGinnis \& Gentry, 2004). This reinforces previous studies which emphasise the interdependent nature of communitas, flow and ecstasy, and how together each serves as vital components of 'play' (Taheri et al., 2016). As such, this study also posits the relevance of this second-order construct in another, less obvious setting. Extant research has investigated play in nightclubs and commercial hospitality (Taheri et al., 2016), service encounters (McGinnis et al., 2008), adventure tourism (Gyimóthy, \& Mykletun, 2004), and sporting activities (McGinnis et al., 2012). Instead, the relevance of this construct is now established in the context of religious pilgrimage.

This paper contributes to the investigation of the self-expression construct in relation to play (McGinnis et al., 2008). Indeed, the findings suggest that self-expression has a strong positive and significant influence on play. Play is realised if (and when) an individual can express themselves and augment their self-image through a specific experience, situation or product (Gross \& Brown, 2008). The findings therefore correspond with existing research, where individuals engaging in activities and consuming products which allow them to express their self-concept, are likely to experience feelings of exhilaration or ecstasy (Prayag \& Hosany, 2014). Tourists undertaking Umrah regard it as a mechanism to expose their true selves, subsequently experiencing euphoria. Given the religious nature such travel, these religious tourists are surrounded by fellow worshipers in an environment where the event expresses and reinforces one aspect of their identity (Henderson, 2009). Therefore, feelings of ecstasy are likely to ensue from this situation that reflects their self-image.

Similarly, the association between self-expression and play found in this study is also supported by prior research (e.g., McGinnis et al., 2008; Hopkinson \& Pujari, 1999). Indeed the Umrah and pilgrimage environment is one characterised by religious congregation where 
individuals engage in an experience enabling self-reflection. The ideal experience or flow, where individuals lose a sense of time while escaping from the pressures of everyday life, is a product of the tourist's ability to project their own self-concept in a particular social group. This reinforces research suggesting that the potency of sacred places as consumption environments stimulate feelings of flow (McGinnis et al., 2008). Further, the findings support the association between self-expression and communitas (Hopkinson \& Pujari, 1999; McGinnis \& Gentry, 2004). Feelings of togetherness, belonging and collective harmony among those experiencing Umrah and the ability to express their true identity fit well within the pilgrimage context. Studies highlight that communitas occurs during shared experiences (Gannon et al., 2017), and those travelling for Umrah experience feelings of camaraderie and shared experiences as they regard such tourism as reflecting themselves and exposing their self-concept, manifest through sharing the pilgrimage with fellow worshipers (Jafari \& Scott, 2014). Given that self-expression is a significant element of the Umrah experience, and pilgrimage is a setting which brings travellers of similar beliefs together for the same purpose, the motivation to undertake shared experiences and get to know fellow travellers is expected.

The hedonic nature of consumption experiences, especially in tourism, is established (Hightower Jr et al., 2002). However, this study sheds further light on the relationship between play and hedonism. The findings highlight that play has a positive and significant impact on hedonism. The pleasure gained from 'sacred' experiences has been recognised in previous studies (Hyde \& Harman, 2011; Mason \& Paggiaro, 2012). The collective nature of pilgrimage, and voluntary nature of Umrah, therefore reinforces the value of Islamic tourism by providing an environment where shared experiences and a sense of belonging are typical (Eickelman \& Piscatori, 2013). The findings therefore suggest that, through a sense of amity with a situation saturated with notions of worship and social cohesion, feelings of enjoyment (with regards to both the spiritual and non-spiritual value derived from such travel) are cultivated. Therefore, the findings support previous studies by highlighting the relationship between play and hedonism (Arnould \& Price, 1993; Hopkinson \& Pujari, 1999), while extending Islamic tourism and consumption research by reinforcing the interconnected nature of the 'sacred' and the 'selfish' within the pilgrimage environment (Eid \& El-Gohary, 2015; Moufahim \& Lichrou, 2019)

The opportunity for individuals to escape their daily lives and engage in unforgettable activities transcending time is indicative of travel and tourism, and this is reflected in our findings. Specifically, the voluntary nature of Umrah and feelings of flow which result from 
tourists' experiences naturally stimulate delight and escapism. Similarly, feelings of ecstasy are associated with hedonism (Dunham et al., 2006). Indeed, the enjoyment of a sacred experience has been inherently associated with euphoria (Grappi \& Montanari, 2011). Specially, the pilgrimage environment engenders heightened levels of ecstasy, beyond that of everyday religious experiences. Therefore, this positive relationship, particularly with regards to ecstasy, is somewhat anticipated. Nevertheless, the positive relationship between play and hedonism highlighted within this study is theoretically significant, adding to the growing body of knowledge on the non-religious, rather than spiritually traditional, outcomes of the pilgrimage experience.

Supporting other studies (Jang et al., 2000; Prayag \& Hosany, 2014), the findings demonstrate that self-expression has a positive and significant relationship with hedonism. This signifies that the symbolic meaning of the activity, in this context Umrah, enables tourists to express themselves comfortably, and generates feelings of enjoyment and pleasure. The findings indicate that self-expression indirectly impacts on hedonism through play. Unlike previous studies, using self-expression and hedonism together as a progenitor for enduring involvement (McGinnis et al., 2008), this study provides different perspectives of the relationship of self-expression in relation to play and hedonism. Here, it suggests that self-expression is positively associated with play, resulting in feelings of enjoyment or hedonism; self-expression is therefore a significant precursor for playful and pleasurable experiences, even in the religious pilgrimage travel context.

As such, by prioritising the importance of play, destination managers and marketers involved in developing the experiential elements of Umrah can increase tourists' enjoyment of the non-religious aspects of pilgrimage. While the spiritual nature of Islamic travel remains dominant (Damari \& Mansfeld, 2016), the hedonistic nature of such travel is an important element for those undertaking voluntary pilgrimage manifest as Umrah. Managers should therefore strive to create environments that catalyse play - where group camaraderie, escapism and positive emotional reactions are also considered sacrosanct - adding to the experiential nature of the pilgrimage in their own unique way. This could be accomplished by providing opportunities for organising group activities, e.g. day trips and shared eating spaces - enabling the interaction and shared experiences that even religious tourists crave (Gannon et al., 2017; Yalinay et al., 2018). 
Further, those organizing and managing Umrah should not shy away from promoting the 'playful' and self-gratifying elements of this voluntary pilgrimage (Eid \& El-Gohary, 2015). Far from focussing solely on the religious importance of Umrah, managers should instead embrace the fact that it is not obligatory; instead focussing on the social and hedonic benefit that can be derived from enjoyable travel which simultaneously has the power to affirm religious faith. Indeed, as a result of its voluntary nature, Umrah may in fact represent an as-yet untapped vessel for self-expression and play in the Islamic tourism context, where religious tourists choose to undertake pilgrimage for a wider, more rounded and self-fulfilling purpose than its innate spiritual value. As such, understanding the importance of the interplay between self-expression, play and hedonism outlined in the findings is also useful for destination marketers. Those marketing Umrah, despite its innate religious focus, should consider using images of companionship, excitement and escapism to appeal to Islamic tourists' self-image. While not new in tourism research, the religious nature and sensitivity of pilgrimage often subdues the more pleasurable elements and 'lure of the voyage' in marketing activities. When exploring the hedonic nature of 'mass tourism' for Muslims, Jafari and Scott (2014) state that 'Islamic travel instead is proposed as an alternative to this hedonic conceptualization of tourism'. However, our findings suggest that destination marketers must remain cognisant of both the hedonistic and spiritual nature of religious travel in order to reflect the subtlety of tourists' expectations, behaviours, and motivations inherent within the Islamic pilgrimage context.

\section{Limitations and Future Research}

Despite offering embryonic insight into the non-spiritual characteristics of religious tourism, the limitations of this study must be acknowledged. First, questionnaires were used to collect the data. While this approach is established and valid, it is not without weakness. A qualitative approach may provide greater insight into different perspectives in deeper descriptive depth. Therefore, future studies may wish to explore the conceptual model presented in this study using a qualitative approach. This could further inform the model and highlight interesting avenues arising tangentially from the findings of this study. Second, the specific nature of the context of this research - Iranian tourists visiting Mecca on the voluntary holy pilgrimage of Umrah - limits the generalisability of the model and findings due to its religious and geographical specificity. Future research should explore the model proposed in this study in different contexts - both religious and non-religious - in order to extend its application and test it further. Finally, as mentioned prior, the sample was restricted 
to Iranian visitors to Umrah. Given the inherent differences in cultures that exist across nationalities, future studies should investigate the conceptual model using a sample of visitors from other nationalities to determine its validity across various sub-sections of the Islamic tourism community. 


\section{REFERENCES}

Albayrak, T., Herstein, R., Caber, M., Drori, N., Bideci, M., \& Berger, R. (2018). Exploring religious tourist experiences in Jerusalem: The intersection of Abrahamic religions, Tourism Management, 69, 285-296.

Allen, M.W. (2001). A practical method for uncovering the direct and indirect relationships between human values and consumer purchases. Journal of Consumer Marketing, $18(2), 102-120$.

Armstrong, J. S., \& Overton, T. S. (1977). Estimating nonresponse bias in mail surveys. Journal of Marketing Research, 14(3), 396-402.

Arnould, E.J., \& Price, L.L. (1993). River magic: extraordinary experience and the extended service encounter. Journal of Consumer Research, 20(1), 24-45.

Arnold, M.J., \& Reynolds, K.E. (2012). Approach and avoidance motivation: investigating hedonic consumption in a retail setting. Journal of Retailing, 88(3), 399-411.

Aukland, K. (2017). 'Pilgrimage Expansion through Tourism in Contemporary India: The Development and Promotion of a Hindu Pilgrim Circuit', Journal of Contemporary Religion. 32(2): 283-98.

Babin, B.J., Darden, W. R., \& Griffin, M. (1994). Work and/or fun: measuring hedonic and utilitarian shopping value. Journal of Consumer Research, 20(4), 644-656.

Babin, B.J., Lee, Y.K., Kim, E.J., and Griffin, M. (2005). Modelling consumer satisfaction and word-of-mouth: restaurant patronage in Korea. Journal of Services Marketing, 19(3), 133-139.

Barber, R.W. (1993). Pilgrimages. London, UK: Boydell Press.

Barnett, L. (2000). Play. In. Jafari, J. (ed.) Encyclopedia of Tourism (442-444), London: Routledge.

Becker, J.M., Klein, K., \& Wetzels, M. (2012). Hierarchical Latent Variable Models in PLSSEM: Guidelines for Using Reflective-Formative Type Models. Long Range Planning, 45, 359-394.

Belk, R.W., Wallendorf, M., \& Sherry, J.F. (1989). The sacred and the profane in consumer behavior: Theodicy on the odyssey. Journal of Consumer Research, 16(1), 1-38.

Celsi, R.L., Rose, R.L., \& Leigh, T.W. (1993). An exploration of high-risk leisure consumption through skydiving. Journal of Consumer Research, 20(1), 1-23.

Collins-Kreiner, N., \& Kliot, N. (2000). Pilgrimage Tourism in the Holy Land: The Behavioural Characteristics of Christian Pilgrims. GeoJournal, 50(1), 55-67.

Collins-Kreiner, N. (2010). Researching pilgrimage: Continuity and transformations. Annals of Tourism Research, 37(2), 440-456.

Cordina, R., Gannon, M. J., \& Croall, R. (2018). Over and over: local fans and spectator sport tourist engagement. The Service Industries Journal, doi:10.1080/02642069.2018.1534962

Crompton, J.L., \& McKay, S.L. (1997). Motives of Visitors Attending Festival Events. Annals of Tourism Research, 24(2), 425-39.

Curran, R., Baxter, I.W., Collinson, E., ...\& Yalinay, O. (2018). The traditional marketplace: serious leisure and recommending authentic travel. The Service Industries Journal, 38(15-16), 1116-1132.

Csikszentmihalyi, M. (1975). Beyond boredom and anxiety. San Francisco: Jossey-Bass.

Dallen, J.T., \& D.H. Olsen (2006). 'Tourism and Religious Journeys', pp.1-22 in T.J. Dallen and D.H. Olsen (Eds.) Tourism, Religion and Spiritual Journeys. Abingdon: Routledge.

Damari, C., \& Mansfeld, Y. (2016). Reflections on pilgrims' identity, role and interplay with the pilgrimage environment. Current Issues in Tourism, 19(3), 199-222. 
Delener, N. (1994). Religious Contrasts in Consumer Decision Behaviour Patterns: Their Dimensions and Marketing Implications. European Journal of Marketing, 28(5), 3653.

Devereux, C., \& Carnegie, E. (2006). Pilgrimage: Journeying beyond self. Tourism Recreation Research, 31(1), 47-56.

Dunham, L., Freeman, R.E., \& Liedtka, J. (2006). Enhancing stakeholder practice: A particularized exploration of community. Business Ethics Quarterly, 16(1), 23-42.

Eickelman, D.F., \& Piscatori, J. (2013). Muslim Travellers: Pilgrimage, migration and the religious imagination. Routledge, UK.

Eid, R., \& El-Gohary, H. (2015). The role of Islamic religiosity on the relationship between perceived value and tourist satisfaction, Tourism Management, 46, 477-488.

El-Bassiouny, N. (2014). The one-billion-plus marginalization: Toward a scholarly understanding of Islamic consumers, Journal of Business Research, 67, 42-49.

Fam, K.S., Waller, D.S., \& Erdogan, B.Z. (2004). The influence of religion on attitudes towards the advertising of controversial products. European Journal of Marketing, 38(5/6), 537-555.

Faul, F., Erdfelder, E., Buchner, A. \& Lang, A.G. (2009) Statistical power analyses using G*Power 3.1: Tests for correlation and regression analyses, Behavior Research Methods, 41 (4): 1149-60.

Fillis, I., \& Mackay, C. (2014). Moving beyond fan typologies: The impact of social integration on team loyalty in football. Journal of Marketing Management, 30(3-4), $334-363$

Fleischer, A. (2000). The tourist behind the pilgrim in the Holy Land. International Journal of Hospitality Management, 19(3), 311-326.

Gannon, M.J., Baxter, I.W., Collinson, E., Curran, R...\& Maxwell-Stuart, R. (2017). Travelling for Umrah: destination attributes, destination image, and post-travel intentions. The Service Industries Journal, 37(7-8), 448-465.

Grappi, S., \& Montanari, F. (2011). The role of social identification and hedonism in affecting tourist re-patronizing behaviours: The case of an Italian festival. Tourism Management, 32(5), 1128-1140.

Griffin, K.A. (2007) 'The Globalization of Pilgrimage Tourism? Some Thoughts from Ireland', pp.15-34 in R. Raj and N.D. Morpeth (Eds.) Religious Tourism and Pilgrimage Festival Management: An International Perspective. Wallingford: CAB International.

Gross, M.J., \& Brown, G. (2006). Tourism experiences in a lifestyle destination setting: The roles of involvement and place attachment. Journal of Business Research, 59(6), 696700.

Gross, M.J., \& Brown, G. (2008). An empirical structural model of tourists and places: Progressing involvement and place attachment into tourism. Tourism Management, 29(6), 1141-1151.

Gyimóthy, S., \& Mykletun, R.J. (2004). Play in adventure tourism: The case of Arctic trekking. Annals of Tourism Research, 31(4), 855-878.

Hair, J.F.J., Black, W.C., Babin, B.J., \& Anderson, R.E. (2010). Multivariate Data Analysis: A Global Perspective. USA: Pearson.

Hair, J.F.J., Hult, G.T.M., Ringle, C.M., and Sarstedt, M. (2014). A primer on Partial Least Squares Structural Equation Modeling (PLS-SEM). United Kingdom: Sage.

Hair, J.F., Sarstedt, M., Ringle, C.M., \& Gudergan, S.P. (2017). Advanced issues in partial least squares structural equation modeling. SAGE Publications.

Hellman, J. (2017). Pilgrim guides and pilgrims in productive complicity: Making the invisible visible in West Java. Tourist Studies, doi: 10.1177/1468797617723765. 
Henderson, J.C. (2009). Islamic tourism reviewed. Tourism Recreation Research, 34(2), $207-$ 211.

Henseler, J., Hubona, G., \& Ray, P.A. (2016), Using PLS path modelling in new technology research: Updated guidelines, Industrial Management and Data Systems, 116(1), 2120.

Henseler, J., Ringle, C. M., \& Sarstedt, M. (2015). A new criterion for assessing discriminant validity in variance-based structural equation modeling. Journal of the Academy of Marketing Science, 43(1), 115-135.

Heo, J., Lee, Y., McCormick, B.P., \& Pedersen, P.M. (2010). Daily experience of serious leisure, flow and subjective well-being of older adults. Leisure Studies, 29(2), 207225.

Hightower Jr, R., Brady, M.K., \& Baker, T.L. (2002). Investigating the role of the physical environment in hedonic service consumption: an exploratory study of sporting events. Journal of Business Research, 55(9), 697-707.

Hirschman, E.C., \& Holbrook, M.B. (1982). Hedonic consumption: emerging concepts, methods and propositions. The Journal of Marketing, 46(3), 92-101.

Hopkinson, G.C., \& Pujari, D. (1999). A factor analytic study of the sources of meaning in hedonic consumption. European Journal of Marketing, 33(3/4), 273-294.

Hosany, S., \& Gilbert, D. (2010). Measuring tourists' emotional experiences toward hedonic holiday destinations. Journal of Travel Research, 49(4), 513-526.

Hyde, K.F., \& Harman, S. (2011). Motives for a secular pilgrimage to the Gallipoli battlefields. Tourism Management, 32(6), 1343-1351.

Jafari, J., \& Scott, N. (2014). Muslim world and its tourisms. Annals of Tourism Research, $44,1-19$.

Jang, H.C., Lee, B., Park, M., \& Stokowski, P.A. (2000). Measuring underlying meanings of gambling from the perspective of enduring involvement. Journal of Travel Research, $38(3), 230-238$.

Jutla, R.S. (2002). Understanding Sikh Pilgrimage. Tourism Recreation Research, 27(2), 6572.

Kleine III, R.E., Kleine, S.S., \& Kernan, J.B. (1993). Mundane consumption and the self: a social-identity perspective. Journal of Consumer Psychology, 2(3), 209-235.

Kyle, G., \& Chick, G. (2002). The social nature of leisure involvement. Journal of Leisure Research, 34(4), 426-448.

Lee, C., Hallak, R., \& Sardeshmukh, S.R. (2016). Innovation, entrepreneurship, and restaurant performance: A higher-order structural model. Tourism Management, 53, 215-228.

Liang, H., Saraf, N., Hu, Q., \& Xue, Y. (2007). Assimilation of Enterprise Systems: The Effect of Institutional Pressures and The Mediating Role of Top Management. MIS Quarterly, 31(1), 59-87.

Mannell, R.C., \& Iso-Ahola, S.E. (1987). Psychological nature of leisure and tourism experience. Annals of Tourism Research, 14(3), 314-331.

Mannell, R.C., \& Kleiber, D.A. (1997). A social psychology of leisure. State College: Venture Publishing Inc.

Mathras, D., Cohen, A.B., Mandel, N., \& Mick, D.G. (2016). The effects of religion on consumer behavior: A conceptual framework and research agenda, Journal of Consumer Psychology, 26(2), 298-311.

Mason, M.C., \& Paggiaro, A. (2012). Investigating the role of festivalscape in culinary tourism: The case of food and wine events. Tourism management, 33(6), 1329-1336.

Mazumdar, S., \& Mazumdar, S. (2004). Religion and place attachment: A study of sacred places. Journal of Environmental Psychology, 24(3), 385-397. 
McGinnis, L.P., \& Gentry, J.W. (2004). Examining the Mediating Relationship of Aplay@ on Ritual Enduring Involvement. NA-Advances in Consumer Research, 31.

McGinnis, L.P., Gentry, J.W., \& Gao, T. (2008). The impact of flow and communitas on enduring involvement in extended service encounters. Journal of Service Research, 11(1), 74-90.

McGinnis, L.P., Gentry, J.W., \& Gao, T. (2012). Antecedents to Consumer Perceptions of Sacredness in Extended Service Experiences: The Case of Golf. Journal of Service Research, 15(4), 474-488.

Moore, K., Cushman, G., \& Simmons, D. (1995). Behavioral conceptualization of tourism and leisure. Annals of Tourism Research, 22(1), 67-85.

Moufahim, M., \& Lichrou, M. (2019). Pilgrimage, consumption and rituals: Spiritual authenticity in a Shia Muslim pilgrimage. Tourism Management, 70, 322-332.

Nyaupane, G.P., Timothy, D.J., \& Poudel, S. (2015). Understanding tourists in religious destinations: A social distance perspective. Tourism Management, 48, 343-353.

O'Shaughnessy, J., \& Jackson-O'Shaughnessy, N. (2002). Marketing, the consumer society and hedonism. European Journal of Marketing, 36(5/6), 524-547.

Podsakoff, P.M., MacKenzie, S.M., Lee, J., \& Podsakoff, N.P. (2003). Common method variance in behavioral research: a critical review of the literature and recommended remedies. Journal of Applied Psychology, 88(5), 879-903.

Prayag, G., \& Hosany, S. (2014). When Middle East meets West: Understanding the motives and perceptions of young tourists from United Arab Emirates. Tourism Management, 40, 35-45.

Ringle, C.M., Wende, S., \& Becker, J.M. (2014). SmartPLS 3.0, from http://www.smartpls.com/

Roccas, S. (2005). Religion and value systems. Journal of Social Issues, 61(4), 747-759.

Saroglou, V. (2011). Believing, Bonding, Behaving, and Belonging The Big Four Religious Dimensions and Cultural Variation. Journal of Cross-Cultural Psychology, 42(8), 1320-1340.

Schau, H.J., Gilly, M.C., \& Wolfinbarger, M. (2009). Consumer identity renaissance: the resurgence of identity-inspired consumption in retirement. Journal of Consumer Research, 36(2), 255-276.

Schmidt, R., Sager, G.C., Carney, G., Jackson, J.J., Zanca, K., Muller, A., \& Jackson, J. (1999). Patterns of religion. Belmont, CA:Wadsworth Publishing.

Scott, L.M. \& Maclaren, P. (2013). Consuming the mists and myths of Avalon. In D. Rinallo, L.M. Scott \& P. Maclaren (Eds.) Consumption and Spirituality. Vol.16 (pp.195-210). NY, Routledge, pp.16.

Sharpe, E.K. (2005). Delivering Communitas: Wilderness Adventure and the Making of Community. Journal of Leisure Research, 37(3), 255-80.

Sharpley, R., \& Jepson, D. (2011). Rural tourism: A spiritual experience?. Annals of tourism research, 38(1), 52-71.

Smith, L. (2017). Hajj 2017: Two million Muslim pilgrims from all over the world head to Mecca. [online]. Available at: https://www.independent.co.uk/news/world/middleeast/hajj-2017-muslim-pilgrimage-mecca-islam-pilgrims-saudi-arabia-a 7917851.html [accessed 20/01/2018].

Smith, M., \& Ram, Y. (2017). Tourism, landscapes and cultural ecosystem services: a new research tool. Tourism Recreation Research, 42(1), 113-119.

Sonmez, S. (2001). Tourism Behind the Veil of Tourism: Women and Development in the Middle East. In Y. Apostolopoulos, S. Sonmez and D.J. Timothy (Eds.), Women as producers and consumers of tourism in developing regions (pp.113-142). Westport: Praeger. 
Spilka, B., Hood, R., Hunsberger, B., \& Gorsuch, R. (2003). The psychology of religion: An empirical approach. New York: The Guilford Press.

Taheri, B. (2015). Emotional Connection, Materialism, And Religiosity: An Islamic Tourism Experience. Journal of Travel and Tourism Marketing, 33(7), 1011-1027.

Taheri, B., Farrington, T., Gori, K., Hogg, G., O'Gorman, K. (2017). Escape, entitlement, and experience: liminoid motivators within commercial hospitality, International Journal of Contemporary Hospitality Management, 29(4), 1148-1166.

Taheri, B., Gori, K., O'Gorman, K., Hogg, G., \& Farrington, T. (2016). Experiential liminoid consumption: the case of nightclubbing. Journal of Marketing Management, 32(1-2), 19-43.

Taheri, B., Jafari, A., \& O'Gorman, K. (2014). Keeping your audience: Presenting a visitor engagement scale. Tourism Management, 42, 321-329.

Taylor, M., \& Taylor, R. (1997).Something for the weekend, sir? Leisure, ecstasy and identity in football and contemporary religion, Leisure Studies, 16:1, 37-49.

Terzidou, M., Scarles, C., \& Saunders, M.N.K. (2018). The complexities of religious tourism motivations: Sacred places, vows and visions, Annals of Tourism Research, 70, 54-65.

Thompson, J., Baxter, I.W., Curran, R.,...\& Yalinay, O. (2018). Negotiation, bargaining, and discounts: generating WoM and local tourism development at the Tabriz bazaar, Iran. Current Issues in Tourism, 21(11), 1207-1214.

Turner, V. (1969). The Ritual Process: Structures and AntiStructure. Chicago: Aldine Publishing Company.

Turner, V., \& Turner, E. (1978). Image and Pilgrimage in Christian Culture. New York: Columbia University Press.

Vespestad, M.K., \& Lindberg, F. (2011). Understanding nature-based tourist experiences: An ontological analysis. Current Issues in Tourism, 14(6), 563-580.

Vitterso, J., Vorkinn, M., \& Vistad, O.I. (2001). Congruence between recreational mode and actual behavior - a prerequisite for optimal experiences? Journal of Leisure Research, 32(3), 137-159.

Vukonić, B. (1996). Tourism and religion. Emerald Group Publishing.

Wearing, S.L., McDonald, M., \& Wearing, M. (2013). Consumer culture, the mobilisation of the narcissistic self and adolescent deviant leisure, Leisure Studies, 32(4), 367-381

Wells, V.K., Taheri, B., Gregory-Smith, D., \& Manika, D. (2016). The role of generativity and attitudes on employees home and workplace water and energy saving behaviours, Tourism Management, 56, 63-74.

Whiting, J., \& Hannam, K. (2015). Creativity, self-expression and leisure. Leisure studies, $34(3), 372-384$.

Wichmann, A. (2017). Participating in the World Gymnaestrada: an expression and experience of community, Leisure Studies, 36(1), 21-38.

Williams, A., \& MacKinnon, D.P. (2008). Resampling and distribution of the product methods for testing indirect effects in complex models. Structural Equation Modeling, 15(1), 23-51.

Wu, C.H.J., \& Liang, R.D. (2011). The relationship between white-water rafting experience formation and customer reaction: a flow theory perspective. Tourism Management, $32(2), 317-325$.

Yalinay, O., Baxter, I.W., Collinson, E.,...\& Thompson, J. (2018). Servicescape and shopping value: the role of negotiation intention, social orientation, and recreational identity at the Istanbul Grand Bazaar, Turkey. Journal of Travel \& Tourism Marketing. 35(9), 1132-1144. 
Zamani-Farahani, H. \& Ghazali, M. (2012). The Relationship between Islamic Religiosity and Residents' Perceptions of Socio-Cultural Impacts of Tourism in Iran: Case Studies of Sare'in and Masooleh. Tourism Management, 33(4), 802-14. 
Table 1. Assessment of the measurement model.

\begin{tabular}{|c|c|c|c|c|}
\hline Construct item & Loading & $\mathrm{CR}$ & AVE & $\alpha$ \\
\hline Play-Ecstasy & & 0.733 & 0.524 & 0.733 \\
\hline $\begin{array}{l}\text { I often lose control when I undertake religious experiences } \\
\text { due to extreme excitement. }\end{array}$ & 0.773 & & & \\
\hline $\begin{array}{l}\text { When I undertake religious experiences, I often become } \\
\text { spiritually uplifted. }\end{array}$ & 0.744 & & & \\
\hline $\begin{array}{l}\text { When I undertake religious experiences, I often lose my } \\
\text { mind in rapture. }\end{array}$ & 0.760 & & & \\
\hline $\begin{array}{l}\text { When I undertake religious experiences, I get caught in a } \\
\text { state of euphoria. }\end{array}$ & 0.752 & & & \\
\hline $\begin{array}{l}\text { When I undertake religious experiences, I easily become } \\
\text { ecstatic. }\end{array}$ & 0.746 & & & \\
\hline $\begin{array}{l}\text { When I experience religion, I often experience a joy that is } \\
\text { beyond measure. }\end{array}$ & 0.713 & & & \\
\hline $\begin{array}{l}\text { When I undertake religious experiences, I often become } \\
\text { elated. }\end{array}$ & 0.787 & & & \\
\hline Play-Communitas & & 0.928 & 0.682 & 0.906 \\
\hline
\end{tabular}

When I undertake religious experiences, I feel a sense of 0.863 camaraderie.

When I undertake religious experiences, I feel a bond with 0.756 my fellow visitors that I could not experience away from the experience.

When I undertake religious experiences, I feel a sense of 0.781 belonging with others.

When I undertake religious experiences, I feel a sense of 0.907 harmony with the others.

When I undertake religious experiences, I feel a sense of 0.844 sharing feelings with the people there.

This religious experience really allows me to get to know 0.796 my fellow visitors.

Play- Flow

$\begin{array}{lll}0.907 & 0.585 & 0.880\end{array}$

This religious experience is an enjoyable release from the 0.745 everyday grind.

This religious experience is the best way to relieve my 0.720 stress.

When involved in religious experiences, it receives my 0.806 total concentration.

When involved in religious experiences, I am surprised to 0.734

find I have lost track of time

When involved in religious experiences, I can become 0.835

totally involved in what I am doing.

When involved in religious experiences, time seems to rush 0.812

by quickly.

I find a religious experience to be very liberating. 0.785

Self-Expression

$0.891 \quad 0.581 \quad 0.852$

When I engage in tourism experiences I can really be 0.804 myself.

When I engage in tourism experiences, others see me the 0.760 
way I want them to see me.

My choice of tourism experiences says a lot about who I 0.786

am.

Where I engage in tourism experiences gives a glimpse of 0.734

the type of person I am.

You can tell a lot about a person by whether or not they 0.824

engage in tourism experiences.

My tourism experiences are a reflection of my lifestyle. $\quad 0.836$

Hedonism

$\begin{array}{lll}0.851 & 0.613 & 0.751\end{array}$

This experience was truly enjoyable. 0.901

I truly felt it was an escape.

I enjoyed the experience for its own sake. 0.908

I truly felt delighted.

0.725

Note: Significant at ${ }^{*} t>1.96$ at $p<.05 ;{ }^{* *} t>2.57$ at $p<.01 ; * * * t>3.29$ at $p<.001$.

Table 2. Correlations between constructs.

\begin{tabular}{|c|c|c|c|c|c|c|c|c|}
\hline & (1) & (2) & (3) & (4) & (5) & (6) & $\begin{array}{l}\text { Mea } \\
n\end{array}$ & SD \\
\hline (1)Communitas-play & 0.826 & & & & & & $\begin{array}{l}4.88 \\
0\end{array}$ & 1.390 \\
\hline (2)Ecstasy-play & $\begin{array}{l}0.435^{*} \\
*\end{array}$ & 0.723 & & & & & $\begin{array}{l}3.92 \\
7\end{array}$ & 0.947 \\
\hline (3)Flow-play & $\begin{array}{l}0.513^{*} \\
* *\end{array}$ & $\begin{array}{l}0.547 * \\
* *\end{array}$ & 0.765 & & & & $\begin{array}{l}4.46 \\
6\end{array}$ & $\begin{array}{l}1.131 \\
3\end{array}$ \\
\hline (4)Hedonism & 0.332 & $\begin{array}{l}0.555^{*} \\
* *\end{array}$ & $\begin{array}{l}0.605^{*} \\
*\end{array}$ & 0.783 & & & $\begin{array}{l}4.78 \\
7\end{array}$ & 1.314 \\
\hline (5)Play & $\begin{array}{l}0.540^{*} \\
*\end{array}$ & $\begin{array}{l}0.595 * \\
*\end{array}$ & 0.454 & $0.507^{*}$ & $\mathrm{n} / \mathrm{a}$ & & $\mathrm{n} / \mathrm{a}$ & $\mathrm{n} / \mathrm{a}$ \\
\hline (6)Self-expression & $\begin{array}{l}0.572 * \\
*\end{array}$ & $\begin{array}{l}0.645^{*} \\
* *\end{array}$ & 0.484 & $\begin{array}{l}0.558 * * \\
*\end{array}$ & $\begin{array}{l}0.576 \\
*\end{array}$ & $\begin{array}{l}0.76 \\
2\end{array}$ & $\begin{array}{l}4.87 \\
4\end{array}$ & 1.416 \\
\hline
\end{tabular}

Table 3. Estimates of indirect paths.

\begin{tabular}{lcccc}
\hline Path & Path coefficient & $t$-values & Low CI & High CI \\
\hline Self-expression $\rightarrow$ Play $\rightarrow$ Hedonism & 0.233 & 5.371 & 0.143 & 0.308
\end{tabular}

Note: 95\% confidence intervals $(\mathrm{CI})$ via bootstrapping and 5000 resamplings. 


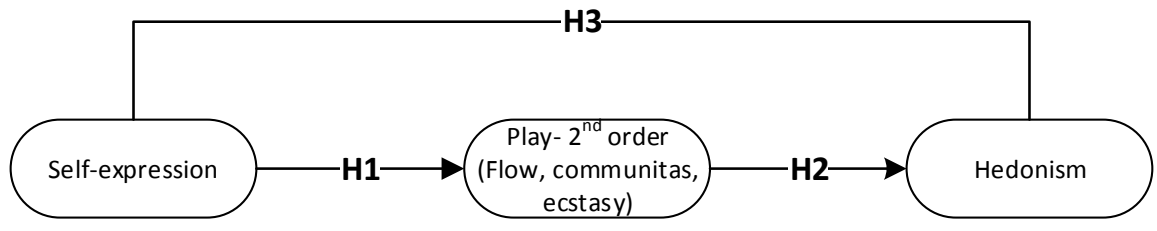

H4: Self-expression $\rightarrow$ Play $\rightarrow$ Hedonism

Figure 1. Conceptual model

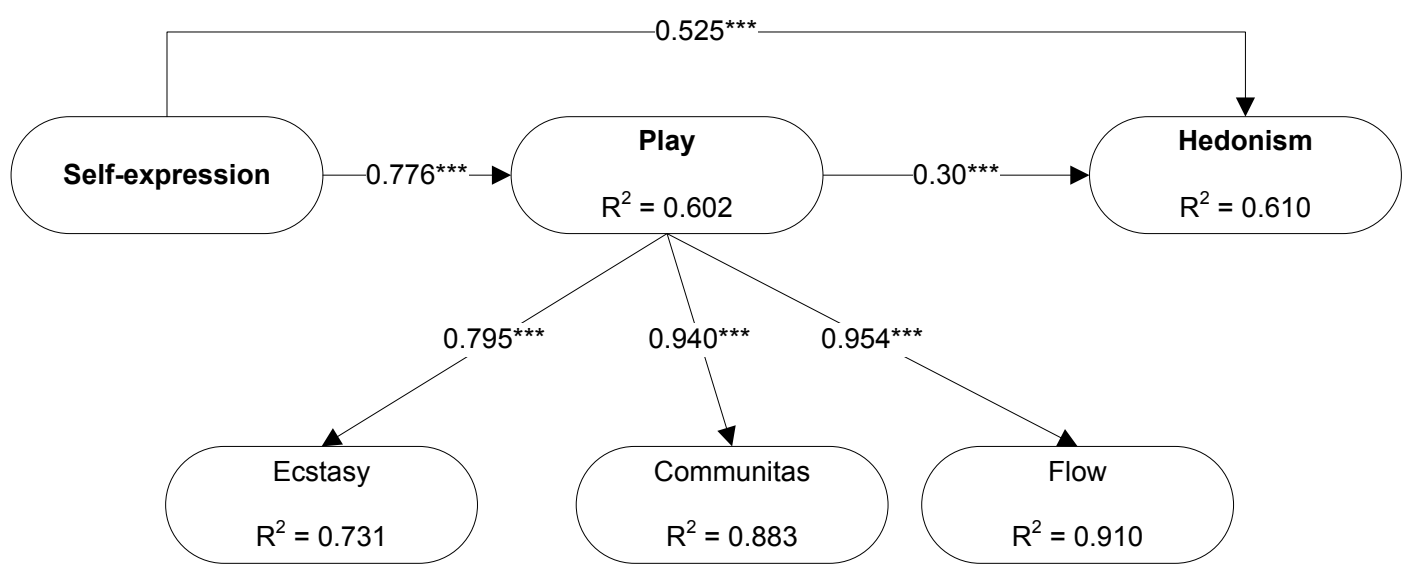

Figure 2. Results of structural model. 